\title{
Craig Lauer
}

\section{Komarov Calling Apollo-Soyuz}

The summer I turned sixteen and finally got my driver's license my grandmother bought me a $\mathrm{CB}$ radio. It was a hand-held one, like the kind road crews talk into, but cheaper. I looked at her as she handed it to me.

"What for?" I said. This was 1983 and the movies Convoy and Smokey and the Bandit had come and gone and any interest I'd had in CBs had gone with them. But we were poor and didn't get new things very often, so I took it from her and tried not to wish she'd gotten me one when I was a lot younger instead, and I pretended I didn't realize what was going on here. See, let me say something right up front about my family: I had a grandmother who worried way too much about me and a mom who's mentally retarded and had to be sent off to live in an institution.

"You're out on your own now. What if the car breaks down? It's my car and I'd never forgive myself. So just take it." She nodded her head and looked very serious. "Please, Jeff."

I was always careful not to hurt her feelings, so I just stood there and stared at the picture of the guy on the box it came in. He was in a skiing outfit and was talking into the CB. I figured he was supposed to be a rescue person, talking about someone who'd just broken his thigh or gotten buried in an avalanche. The seal was broken on the box and I could picture her making the clerk open it up to prove to her it worked. Of course she'd waited until after dinner to give it to me; she liked to have a peaceful meal so we could talk about other things-bigger things. Today we'd managed to keep it limited mostly to my job dealing with weeds for Greener Thumb Landscaping and the clothes shopping for the start of school we were going to have to do soon.

"And would you bring it in with you at night?" she said to me. "The man said this model can't take the heat or cold and I told him I didn't want the model he was trying to sell me."

Upstairs, sitting at the end of my bed, I pulled out the long antenna 
and clicked the $\mathrm{CB}$ on. It scratched and squealed and I flicked from channel to channel with the little dial on top. In the twenties I got some hoarse-voiced guy who I guessed was speeding down one of the bypasses that wasn't too far from our house. I aimed the antenna around my small room, careful not to scrape the walls or hit the crucifix she hung in there, and got him in clearer.

Yeah, yeah, the pork chops at the Neptune are by far the finest in the land. Oh baby, the finest! I could use a side a them mashed potatoes now. Over.

$\mathrm{He}$ said it in a sort of sing-song before his voice disappeared into the static. I kept flicking and got somebody speaking in Spanish whose voice echoed like he was talking over a huge loudspeaker in the middle of a tiled locker room. I'd had two years of Spanish in school and I heard him use the word donde.

It was all kind of depressing because I felt too old to care about it, but I liked having something new, even though I would have preferred something like say a Walkman. But we just didn't get things like that here.

I turned it off and got my shower. I was going out with my friends and I was running late, as usual. We only had a couple weeks left this summer and were trying to squeeze in everything we'd talked about doing once we had a car, which wasn't as much as we'd thought now that we had one. My grandmother let me use her Pacer any night I wanted because she had macular degeneration in her eyes and couldn't drive at night anymore, and probably shouldn't have been driving during the day either, but I wasn't going to say anything. We each got nervous when the other went out, but we kept quiet.

After I was dressed and combed I went downstairs. I was carrying my set of car keys and the CB. She came out from the kitchen to check up on me and I waved it at her and gave her a goofy smile and rolled my eyes as I went out the door.

After dropping off Aaron and James that night, I pulled in around five minutes before midnight. On any given night when I'd come home before my curfew, I'd sit in the parked car across the street from our tiny row home and hang my head out the window. Late in the summer, in the minutes before midnight, Orion stood on a tilt just over 
our brick house when you looked at it from here. The three stars that make up its belt were just above the fake chimney we shared with our neighbor. I liked to look at Orion. Besides the Big and Little Dippers, it was the only constellation I could pick out. I should make clear, I guess, that I'm normal. My mom's thing was nothing genetic; she just didn't get all the oxygen she needed when she was born and so she had brain damage and eventually had to be institutionalized. My grandmother kept her at home while my grandfather was alive, but he died a couple years before I was born and my grandma couldn't handle it on her own. So she sent Mom off to the home where retarded people go who don't have a lot of money and Mom never left for more than a weekend after that, except when she had me.

And that was the Zook family. Except there was a "dad" out there somewhere, but at this point no one could have picked him out of a line-up if they had a gun to their head, Mom included. Actually, Mom especially. All I know is that my grandmother wouldn't talk about it except to say that Mom didn't understand what she was doing and neither did he but look what a gift I am. A real miracle. I decided a long time ago he wouldn't have been any more of a parent than my mom is, or they wouldn't have sent him to a different home without getting even a photograph of him so I could see what he looked like and know if I should worry about having a part of him be a part of me.

That night, when the digital clock that was velcroed to the dashboard changed to 12:00, I dug the CB out from under the front seat where I'd decided to hide it so my friends wouldn't see it. Aaron could be a complete prick. He was rich, which wasn't necessarily a problem, but it was one more thing between us. He'd almost gotten me busted tonight throwing eggs out the window of the Pacer. Things like CBs and retarded moms weren't things I wanted to get into with him.

The engine was still pinging and knocking as I walked away from the car. I worried where we'd get the money for a new one when it finally died. I worried about a lot of things. They'd taken our blood pressure at school recently and had to do mine three times it was so high, but they let it go because I lied and told them I had a huge test coming up I was nervous about. Then I felt lousy about myself when these two old nurses wished me luck on the test. 
I slipped my key into the lock of the front door of the house and quietly let myself in, even though there was no reason to be quiet; I knew she sat up and waited until she heard me.

I went upstairs and got undressed, carrying the CB with me. My grandmother didn't smoke, but I figured I could tell her I picked up that smell at the bowling alley where we sometimes played video games. I flung my clothes into the hamper. I heard her get up and go to the bathroom, clicking the light on only after she'd already shut the door completely, I guess so she wouldn't disturb me with the light. I slipped on some sweat pants and a T-shirt and went back downstairs to get some food, because I was still a little high and hungry, and to get ready to watch Letterman, who was on in twenty minutes.

I brought the CB with me into the basement where the TV was. I didn't think it would be that fun really, but it was something. I flicked on the TV without any sound while Carson was still on and sat on the carpet with my back against the front of the scratchy couch. On the floor around me I spread the bag of Fritos, the dip, peanuts, and my neon green drink which my grandmother liked to call my bug juice. I laughed whenever she said it but I didn't really understand it. I started shoveling the food. I did that sometimes. I'd bought it myself and I liked knowing I could have all I wanted. Doc Severenson's head as it blew on his trumpet was stretched out and his color was weird because we'd had the TV for as long as I could remember and it was just about shot.

The CB was plastic, but it was heavy, like it was packed full of everything it needed to work. I liked the way it felt in my hand. I pulled out the silver antenna and clicked it on and listened to two or three channels to kill time, then I came to channel 39 where I heard the voice of a young man. ". . s scared? Over."

Another young guy came on and said, "I don't know, sometimes, yeah. It's pretty far away. I guess I don't know what it'll be like to be alone ... but I don't know. Over."

"I know. They keep telling me I won't be alone, and everyone'll be in the same boat. But, yeah, I don't know. I still know I'm gonna be alone. . . Maybe we should have gone to the same one."

I didn't know what they were talking about, but I got interested when I heard them. Their voices were kind of sad, and so it sounded 
funny in contrast, but all of a sudden I could hear gunshots and screams in the background of the one who was speaking. "Wait a second," he said. "Hold on, O.K.?"

"Whaddaya got there?" the other one said. "Sounds interesting. Please inform. Over."

He came back on after a second of dead air. "It's nothing. It was HBO."

I lifted the Fritos from my lap and got up and flicked to channel 17, Home Box Office, which I'd finally been allowed to get if I paid for myself, and he was right. Gunshots.

"Hey, what say X-14-13-B-B? Over," the one with HBO said.

"K.O.," the other one said. Then it was quiet. It wasn't too hard to figure out they had some little code, but I flicked around for a while and couldn't find them, even though I went up and down the forty channels five or six times. I wanted to listen to them some more. Letterman was starting, though, so I finally turned off the static and got up and turned up the TV.

A few days went by. We kept the $\mathrm{CB}$ on the bottom rack of the tea cart by the front door. My grandma checked up on me whenever I left, to make sure I was taking it with me. I started teasing her, making sure she was taking it with her as well on the few occasions when she'd drive, saying I didn't want to be responsible if something happened to her. She just said she'd be sure to take it, and she did. She knew how to handle me.

I'd been continuing to listen to it, usually after I came home at midnight. Sometimes even some more after I went up to bed after Letterman-although most mornings I had to get up early for work and my eyes would hurt from lack of sleep and I'd feel a little sick from eating too much junk food. I didn't tell my friends about the CB, even though I wanted to be able to say I got something I really didn't need and that they didn't have, but I knew they wouldn't have been impressed and would have said it was for little kids and dickheads or something. They sometimes said things like this to me, so I shut up.

I'd been scanning around for the two guys I heard the first night. I'd rest the CB on my chest as I lay under my sheet in the dark, with the antenna that must have been six feet long touching the ceiling if I 
took a deep breath. There was a little red button on the front that would make the display light up to show what channel you were on. I listened to truck drivers talking about stupid things that seemed more important and kind of mysterious because it was late at night. I took the time to read about how the CB worked in the little booklet that came with it, which channels were for the police and for emergencies. I never heard anyone say "smokey" or "double nickels" or "bubble gum machine," though all three of these were in the little glossary of CB lingo. I was happy nobody seemed to actually use these words.

I heard a truck driver one night who was from Georgia mention that he was passing by a giant shoe. I knew that shoe. When my grandmother would still take me places-zoo-and-museum-kind-of placeswhen she'd do more than drive to the store or the home where mom was, she'd point it out to me as we passed by it on 30 East, like, look! the shoe! I pictured the truck driver tooling down the road and imagined where he was going. I'd never been out of Pennsylvania for more than an afternoon.

One night, right before Letterman, four or five days after we got the CB, I finally came across the two guys I'd listened to the first night. I'd thought about them since then and decided they lived pretty near each other and were good friends and must not live more than a few miles from me since they came in so clearly. But I could tell they lived in the direction away from town, out in the richer section-I could always tell if someone was richer than I was, and could do it within hearing them say two sentences. I guessed using a phone just didn't do it for them, which I could sort of understand. They talked about how they were both going off to college in a few days. I figured they were going pretty far away. They mentioned McArdle, my high school, but I didn't know who they were from their voices. McArdle was a huge school and they'd just graduated, which meant they were two years ahead of me. They had names for each other-handles my book called them-that they used just when they were first trying to establish contact. Soyuz and Apollo they called each other.

"Soyuz . . A Apollo calling. Come in Soyuz."

"Soyuz here, Apollo. Connection confirmed."

It was really corny, but I was pretty sure I knew what the names meant from when I was real little and sort of into space stuff. They 
were these two spaceships that hooked up and then guys from America and Russia or whatever went back and forth between the two. I was like eight or nine at the time. I figured these two guys had probably been using these names since then and by now didn't know how stupid they sounded, or care.

They both sounded scared about moving away, and though they never said it exactly, they didn't seem to want to give up talking to each other like this. Or that's what I figured anyway, because it's how I think I would have felt if I had someone to talk to like that. I liked listening to them, although whatever little code they'd worked out sometimes threw me off their trail.

One evening after dinner I was sitting outside the home where my mom lived. My grandma didn't always make me go in with her to visit. I often did go in, but she was getting worse and it was kind of hard, and I don't think even my grandma wanted me to see her that way anymore. Usually the guilt would build up and I'd finally go in after a couple of days and hold her hand and take her for a walk, but Grandma knew how it made me feel and that I never asked anyone if I could have a retarded mom please. I did love my mom, if I can just say something like that and not analyze it too much. She was like this huge little baby that did all the things babies do, but Mom didn't even know who I was, except to get more weird and droolly when I was around. She wasn't able to get anyone to understand completely how she ever felt-like she just couldn't get through all the layers of stuff her brain was wrapped up in. That was the worst part-when she'd be sad and there'd be nobody who could do a thing even if we were right there.

I was sitting there waiting for Grandma to finish up and I was tired of flicking up and down on the AM radio, so I dug the CB out from under the front seat. On channel 12 on my first pass I heard the voice of the guy who used the name Apollo.

"Soyuz, come in. Do you copy?"

There was static for a couple of seconds. I admit I really got excited hearing him, like I felt intimate with them in some weird way, maybe just because they weren't completely real to me and had never treated me crappy. 
"Soyuz here. Yeah, I copy."

"How was work today, numb nuts? Did you ask out Rebecca? Over," he said.

"No. God. Marshall is such a donkey sphincter," Soyuz said.

"What did the Lord Marshall do today? Over."

"He had me start measuring out the salt into little paper cups so I don't dump too much on the fries. He said he got a complaint. I would seriously like to implode his testicles with a ballpeen hammer. Over."

"Zoinks," Apollo said. It was a good impression of the goofy guy on Scooby-Doo, which I used to watch.

The residents, as they called the people who lived here, were being taken for their after-dinner walks in front of the building or being pushed around in wheelchairs. I used to kind of like taking Mom on walks, but lately it was getting harder to make her get out of bed. I slouched down in my seat and stuck the antenna out the window. I was feeling really embarrassed, but I pressed the talk button for the first time. My voice didn't sound like mine and I could feel it being heard by people who couldn't see me, which made me nervous, like when I have to talk in class, but I said, "Breaker, breaker, good buddies." I was trying to do a southern accent and I can only swear this was more bold than I usually was. "This is a Mr. Marshall No Balls calling Apollo and Soyuz. Do you copy?” I was breathing heavy I was so embarrassed, but I was laughing too as I let up on the talk button. There was just static for a little while. Then one of them, I think Apollo, came on and said, "Y-93-87-J-Z. Over." I flicked up and down at least fifteen times, listening to police, truck drivers, voices that sounded as if they were coming from the moon, and then, after about five or six minutes, I heard, “. . . major wiener intrusion. Over."

"A royal pain in my scrotal region." It was Apollo talking about down there again. "Whaddaya think? Think we're being monitored? Over."

"I don't know," Soyuz said. "Is there a person with the initials A. H. listening? Repeat. That's the initials $A$. H.?”

I laughed. I didn't say anything so I could keep listening. I liked being a part of this, even though I could hear my friends Aaron and James laughing their asses off at me if they found out.

"Don't say anything incriminating, just in case," Apollo said. 
"You mean like where we hid the body? Over."

"Exactly."

I started to think of breaking in again. I sort of wanted to just talk to them, even though it hit me they'd be moving away soon. But then my grandma opened the passenger door. She was looking pretty pale and depressed. She looked at me as I pulled the antenna in the window and sat up. She wasn't mad-she never showed it really when she got mad-and she tried to joke around by giving me this phony incriminating expression. She didn't get in the car right away but just kept staring at me through the open door. I could tell by how she was trying to make me laugh that she'd had an especially hard time in there. I didn't want to ask her, though. Finally I said, "When are we gonna get a tape deck in here?" and I pushed the CB under my seat.

Thursdays and Sundays I had off from my job yanking and spraying weeds and the next day was Thursday, so I took my grandma around to do some of the things she needed to do. We were at the library so she could get some of her large print books. She liked picking them out on her own even though it was hard for her. While she was off in that section I walked around.

We both kind of wanted to be alone for a little bit. We'd just gotten done at the home again and it was really bad. Grandma hadn't said to me as we pulled up outside that she'd just be a minute, which was the way she let me know it was O.K. if I stayed in the car and didn't have to go in and see Mom, so I'd gone in with her. The guilt. When we got to her room on the second floor, Mom was having one of her tantrums. There were two men and a woman trying to hold her down, which was hard to watch, and the three other grown-ups she shared her room with (two Downs, and a Cerebral Palsy) were out in the hall, mumbling, rocking, staring, wrapping their arms around themselves. She'd messed up her bed again. She was flailing around, and I noticed her hair was greasy even though my grandmother got on them about giving her her bath every day and did it herself sometimes, pulling the curtain around and telling me to go take Jean (Cerebral Palsy) for a walk in her wheelchair. Today it was too much and Grandma got me out of there pretty quickly.

In a little while Grandma checked out her books and came and got me in the reference room. 
After the library, there were some other errands-which we did quietly, being careful around each other because of how hard the home had been today-then dinner. We ate together every night. Even when I wanted to go out and eat with my friends at City Park Mall, or go to McDonald's, she'd make me sit and eat with her. If I didn't want to eat much so I could eat again with my friends later on, that was O.K., just as long as I sat with her for a little while.

She'd talk to me sometimes about my job, school, my future, and about my friends. That was a big topic. She didn't like Aaron and James much; she didn't like the way they treated me. She let me hang out with them, but she'd drop things in like, "Guys who are big in high school don't always turn out so big afterwards. Keep that in mind, Jeff." Or, "Friends don't always stay friends forever." I didn't disagree with her, but I thought she didn't get that the two guys I hung around with were smarter than I was and got better grades (she said I just didn't apply myself), and didn't get all nervous all the time around people like I did. I thought she'd have figured they'd be a good influence on me if anything. And, considering, I might need some influences. She seemed to be talking about something else, though. But our dinners together always stayed peaceful. She'd say things about my friends, but then would always leave me alone, and I wouldn't get on her about sending money we didn't have off to St. Christopher, or driving when she could barely see, or letting Mom stay in that horrible place.

Later on I was completely exhausted and feeling lousy and went up to bed before eleven. I turned on the CB in the dark to see if I could find Soyuz and Apollo. All I had on was my underwear and I was on top of my bedspread. My bed was a little kid bed, a twin with a metal frame, which had been my mom's before she went to the home. I wasn't very tall, but my feet still stuck off the end.

There was static from 23 to 40 , but then I got around to channel 1 and found them. I wanted to break in to talk to them. It was like I wanted to tell them all about Mom and my life and that I was jealous they were leaving, but I couldn't even imagine hearing my own voice right then, or how I'd say what I wanted to say. It was stupid to consider it anyway. They were packing as they talked.

"Man, my room's in boxes," Soyuz said. 
"Yeah, I just took down my posters because Alisa's getting my room. I have to sleep in hers when I come home." He paused and I could hear him shuffling around. I swear I could hear the emptiness in his room in the way his voice echoed. I wondered what the two of them looked like, if I'd recognize them if I saw them. "I can't believe thisI really thought I wanted to go, but I really don't now ... I just packed up my computer to take along; that was the last thing. . . How much more do you have to do? Over."

There was just the static then. Finally, Apollo came on and said as if he couldn't believe it, "Like . . none."

I thought about them going off on their own. I tried to imagine it. I'd gone out for a quick drive with just James earlier-I could talk to him a little easier than Aaron-and had started to say something to him about my mom. I just wanted to talk. I knew he knew she was retarded, even though I never told him really. I think pretty much everyone knew. I probably told someone in second grade or something and now everyone at my high school knew I was the kid with the retarded mom. But tonight it just embarrassed him and that made me embarrassed, which is pretty much how I felt about the whole thing anyway. We got off it. Before I thought more I pressed the button and said, quietly, so I wouldn't wake up my grandmother, "Breaker, breaker, Apollo, Soyuz. This is a Mr. No Balls calling again. Please don't try to get away from me this time. I mean you no harm, gentlemen." I was lowering my voice like I was older and using that lousy southern drawl again.

Soyuz was the first to come on. "What?" I think he was laughing. "What do you want there, No Balls?"

I really didn't know. I just lay there for a second. I wanted to say something to maybe make them feel less scared about things, although I knew I was about the last person in the world qualified to do something like that. Here's what I finally said: I said, "I just wanna say somethin' to you both. I wanna tell you what my mama, God rest her good soul, used to say to me. All right?" I was sort of fixating on the ceiling, although it was too dark to actually see it. "She'd say, 'It's a big world out there, son, and you'll make your way in it just fine. Just be a good person and don't let anyone turn you into anything other. Be a good person and take care of other people."” 
My grandmother actually did say this to me pretty often, but now mostly it was just words for me to use to make me sound more grownup.

After a bit, Soyuz came on and said, "That's nice, No Balls." He laughed. "But what are you ... like twelve?"

I usually got too uptight to talk to people I didn't know, especially if I felt like they didn't really want to be talking to me, but on the CB it was different. I felt more powerful, like I had some control over things.

"No, sir, I'm a little older than twelve," I said, "and definitely old enough to know that you have nothing to fear out there."

"And what exactly qualifies you to know this, No Balls?"

I was walking over to the window as he was talking. I lifted up the screen and leaned out into the warm night air. The antenna stuck up into the sky. "Boys, I've been on the road all my life. Traveling from one town to the next. I left home when I was sixteen after my mama died and there was no one left to look out for me, so I started lookin' out for myself. And here I am today. I've seen this whole country and a lot of some others, too, and I'm here to tell you, there ain't nothin' to be afraid of. You're both gonna be O.K. Better than O.K., in fact."

Soyuz came on after a bit and said, "No Balls ... you are so seriously full of crap."

"You can think that, but I know more than you think I do," I said. "And I know enough to be able to tell you how things are gonna go for you away from home. Tell me where you're going."

"I'm going to Massachusetts," Soyuz said.

"Freaking Florida," Apollo said.

I imagined both states on the map. Sometimes I looked at maps, just to try and understand what was out there.

"What's wrong with Florida?" I asked. To me, then, Florida was the beach and sunshine and easiness and I thought everything anyone could want. I wouldn't have minded taking Grandma and Mom there and just lying on the hot beach for a good long, long while.

"I don't know. My grandparents live there and every time I visit there's nothing but old people. But I'm going to Jacksonville, which isn't where they live and isn't all old people I guess. But it's far away from here." 
I imagined how far. I liked to measure distances on maps and wonder how long it would take to get there. I sometimes imagined walking these distances, but not in any real way, I guess, because I now had trouble picturing Apollo actually going there. But I kept talking: "You're gonna like going away and you won't be sad. You'll come home on holidays. Your parents'll come to visit and you'll get to see your grandparents. And you and your pal Soyuz will always be friends. I can tell that." I think I believed what I was saying, although I felt stupid saying it. "And you, Soyuz," I said, "you're gonna love Massachusetts." I tried to picture what Massachusetts would be like and had trouble except I saw snow and rich, fancy houses and buildings-probably stuff I'd seen on TV-but it seemed as though it would be nice.

"Massachusetts is the right place for you ... I've been there many times and would love to live there if I ever settle down. Tell me when you both leave."

"Saturday," Soyuz said. "Both of us."

So tomorrow was their last day and night here. I had the feeling in my stomach I got when I was jealous of someone. Nobody said anything for a little bit and I imagined they were listening to the same static I listened to. Really childish, but I swished the antenna back and forth, trying to look up at it against the black sky and a ton of stars.

Then Apollo came on and said, "C'mon, No Balls. I know there's no way you're a grown-up, but tell me who you are."

There are those times when for no real reason all of a sudden the bottom drops out of how you feel and you go hollow and depressed and have trouble even talking. I was having trouble talking now. Mom was lying there at the home, probably scared but who would know it, and I was looking out the window of the room where she once lived.

"I'm just a traveling salesman passing through," I said.

"O.K., tell us what you sell," Soyuz said with this smart-ass tone that under the circumstances didn't annoy me.

I said, connecting stars with the tip of the antenna, "Wheelchairs, crutches, things like that."

"Yeah, right," Soyuz said.

"Tell you what, No Balls," Apollo came on and said. "Be back tomorrow ... twelve noon. Channel 12. Apollo out."

"Soyuz out." 
I kept my head out the bedroom window for a while and listened to the static on the CB, which it only took me until then to figure out was nothing but the sound of empty space.

The next day I was at work at the country club where the rich people go. I was on lunch break. I'd spent the morning attacking dandelions and clover and wasn't thrilled about getting back to it because I was tired and hungry. I felt that way a lot. The car was about a thousand degrees when I got to it and I was afraid there'd been a meltdown with the CB, but I'd taken the precaution of wrapping it in a blanket that morning and putting it in the trunk. I had a half hour while I ate my peanut butter and jelly sandwich and ate my pretzels.

I sat under a tree and turned on the CB while I looked out over this fancy golf course. Apollo and Soyuz were already talking on channel 12 and I just listened for a little. I pictured them talking this way for years and envied them. I looked around but I was the only car in this whole part of the lot. It was almost a hundred degrees out and humid but there were still people on the golf course. Sitting under a tree, sweating, drinking the water and bug juice I promised my grandmother I'd drink, I broke in.

"Breaker, breaker, Apollo, Soyuz. Excuse the interruption." I had dropped the southern drawl.

"That you, No Balls?" Apollo asked.

"That's affirmative," I said.

"I wasn't sure you'd get back to us. Over," Soyuz said.

"Well, I'm out here on the golf course and I decided I wanted to say hello and goodbye to my good buddies, Apollo and Soyuz. You're both leaving town tomorrow and so I decided I'll be leaving your town, too. Just wanted to say adios. . . . Heading out for new territory myself tonight."

I knew they knew I was lying.

"Well, it was good knowing you, No Balls," Apollo said, "even though you're so full of crap you can't stand up straight. Over."

I laughed, but not into the CB. Then I pressed the button and said, "It was good getting to talk to you both. It's one of the joys of my life, traveling from town to town, getting to meet people like yourselves." 
"Hey, by the way, No Balls. Really, what's your real name?" Soyuz asked.

I knew he'd ask me this; I'd prepared myself for it. "You're both gonna do all right," I said to drag it out for no real reason. I'd looked up an answer the day before at the library. Finally I got around to saying it. "And my name's Komarov. Mr. V. Komarov."

Komarov had been an astronaut. A cosmonaut actually. I thought they might get it, and that it might please them.

For a second neither of them said anything. Then Soyuz came on and said, "O.K., Komarov. Well, talk to you later, I guess ... And thanks. Over."

"Yeah, thanks, Mr. V. Komarov. Even though you're still completely full of crap. Out."

I didn't care that they didn't get it. I missed them already, though I had no one to tell and no reason to tell them.

Aaron and James came over after work that night, because Friday nights my grandmother sometimes let me order a pizza and skip dinner with her. She'd then go up to bed early and we could sit around in the basement and watch TV or, now that I had my license, go out later on and drive around. I was tired and wasn't really in the mood for Aaron and James, but I had them over anyway.

According to our routine, she called me upstairs around seven with her pocketbook open and told me to order a large plain one, which I then ran and picked up while James and Aaron waited downstairs.

When I got back from the pizza shop (she spared me taking the $\mathrm{CB}$ ), after she took out a single slice for herself and left us the rest, James and Aaron were behind the bar in the basement going through the bottles.

"Hey, man," I whispered. "C'mon, get out of there."

"What the fuck, Zookie? Lighten up," Aaron said.

James came out from behind it and said, "Don't worry, we were being quiet. Your grandmother didn't hear us."

No one ever went back there. I wasn't uptight about drinking or anything; I'd gotten drunk pretty many times, but this had been my grandfather's bar and I didn't feel comfortable seeing them there. 
Aaron held up two bottles of Irish Mist whiskey. One was unopened, one was two-thirds full. "Who drinks all this stuff?" he asked.

I was getting nervous that my grandma was listening and I said, "Jesus, keep it down."

"Does your grandmother drink it?" James asked.

"No. No one does," I whispered. "Well, I do sometimes," I added. It was basically a lie. I'd tasted a couple and had gone back there many times just to stand there. It was a good bar and was filled with expensive-looking things. I'd stand behind it and look out at the rest of the basement.

I got Aaron out from behind it, lifting up the one end that was on a hinge to show him I was serious. He took his time but slowly came out.

"Shit, Zook. We're taking stuff all the time from my parents. Why don't we lift some of this stuff? It's just sitting here going bad."

It's true we'd taken stuff from his parents' liquor cabinet before, like cream sherry and sweet things like that, but they were rich and had a huge cabinet full of the stuff. This was different. We ate the pizza and flicked around through a couple of reruns we weren't into watching. I don't think James was trying to be obnoxious, but he asked, "Man, when are you gonna get a VCR?"

I just shrugged. I was sitting on the floor and so was James, but Aaron was pacing, looking at the pictures on the walls and some souvenirs my grandmother and grandfather got on a trip to Mexico way, way back. Before Aaron and James had come over, I'd taken down a horrible thing my mom had made from yarn and popsicle sticks that my grandmother hung up off in the corner.

"There's some really ugly shit down here," Aaron said. "I mean, no offense, but it's kinda depressing. How do you sit down here?"

"I don't always," I said. Which was sort of true. I split my time between here and my room.

When we were finished I took up the empty pizza box and the plates and utensils Grandma made me bring down. I crumpled up the napkins we didn't use and threw them away and laid some pieces of crust on the plates after wiping some sauce and grease on them. I didn't want her to think I was being defiant by not using them. She 
called out that she'd get the dishes, just leave them, and I asked if she was sure, then left them on the counter.

She was lying on the couch resting her eyes, which was something she did every night after dinner for an hour or so. She said it'd be good for me if I did it too sometimes, but I could never just lie there wide awake for that long.

"I think we might go out for a while. Is it all right if I take the car?" I stepped into the dining room after I asked and watched her as she sat up. "You don't have to get up, Grandma. Stay there."

"That's O.K., honey. I want to get up now."

She looked worn out. She looked up at me and smiled. I knew she couldn't see me very well but I smiled back anyway.

When we left she was already up in her bedroom. I let Aaron and James go out ahead of me and I lifted the CB from the little shelf. Outside, James turned and saw it and asked, "What's that? A walkietalkie?"

I shook my head and pointed upstairs and rolled my eyes, though I didn't mean it. "She makes me carry it-in case her car breaks down."

By then Aaron had dropped back to see what we were talking about.

"Let me see it," he said.

"Hold on." I looked up at her bedroom window. I didn't want her to see me doing anything wrong.

In the car I handed it over to Aaron in the back seat. He clicked it on and, unlike me, right away pressed the talk button and said, "Delta niner omega breaker breaker. Anyone out there?"

Someone came on through the static and said, "I copy breaker." It was a truck driver. I'd discovered you could always tell right away if it was a truck driver.

"Holy shit," Aaron said, "they really talk that way." He pressed the button again. "Where are you located? Do you read me?"

"It's 'do you copy?" I said. I looked in the rearview mirror and he held the $\mathrm{CB}$ up to his mouth but didn't press the talk button. Looking at me he said, "Bite me, Zook. Do you copy?"

James almost hurt himself laughing. James then asked me if I ever listened to it and I shrugged and said I guess a couple of times. I looked at him to see if he was laughing at me.

As soon as we got outside of town I pulled from under my shirt a 
Coke bottle I'd filled with whiskey. They hadn't seen me bring it.

"All fucking right, Zookie," Aaron said. I was looking in the rearview mirror at him.

James said, "Oh man, give me some of that shit."

I handed it over to him. He held it up in front of him and swirled it around like he was judging it or something. I'd had a tiny little sip of the stuff once and knew it tasted like paint thinner and figured they'd never had any, but I didn't say anything. He took a sip, a little one, and made a face.

"Holy Christ," he said.

He handed it back to Aaron, who took a sip. Then in a few seconds he yelled "yee haw!" and stomped his foot on the floor. "Lordy lordy lordy amen!" he yelled. "You're the man, Zook! You're the man!"

We got to the cemetery where we'd been hanging out lately, where my greener thumb had cut grass for a few weeks earlier in the summer, and parked the car around the back of the church. We were out in the boonies and had never seen any sign of a cop, so we didn't worry about it. We walked out to the middle of the cemetery with the CB and the bottle of whiskey. I wasn't exactly a poster boy for not driving drunk, but I figured I wouldn't drink much.

Aaron started flicking around some more, going quickly from channel to channel. He went past one where I could hear Apollo's voice. He went back to it.

". . . south on Crenshaw toward the horse farm," Apollo said.

"I copy," Soyuz responded. "Come down Ferndale Road and we'll pass each other. Over."

"Check out these couple of good buddies," Aaron said, looking at us.

I sat down on the grass beside them. My heart was really going. I was pretending to laugh. I took a tiny sip of the whiskey and handed it back to James.

"Did you ever hear these guys before?" James asked.

I pretended I was listening to them and then slowly shook my head. I lit a cigarette.

Soyuz said, "Flash your high beams during your pass to acknowledge contact. Copy?"

"Roger high beams," Apollo said. "I am now passing Manor Apart- 
ments on my right. Over."

"I'm passing through the intersection at Ferndale and Rohrerstown Pike. We should make contact in no more than thirty seconds."

I knew where they were. We were a couple miles north of them. Aaron took the whiskey from James but just held it on his lap.

"Traffic is light on my approach. I think I have you in my sight at eleven o'clock, confirm. Over."

I imagined the two of them out there somewhere coming at each other in the night, flashing their high beams at each other like crazy, as if it was the most important thing in the world to them. I could picture right where they were.

"Visual contact confirmed," Apollo said. "Whoa! Stay in your lane, dorky!” He was laughing.

"Just practicing my fancy maneuvers."

Aaron said, "Oh my God, what a couple of fags."

I laughed, too.

"Fall into formation," Apollo said.

"Roger," Soyuz said.

"Breaker breaker, queer buddies. Do you copy?" I looked over at Aaron, who was talking into the CB. He looked at me and raised his eyebrows when he said "copy."

Soyuz came on after a few seconds. His tone was quieter than it had been. He said, "Is that you, Komarov?"

Aaron looked at James and me. He was sitting cross-legged in between two gravestones. He pushed the talk button and said, "Uh, yeah. This is Komaroff."

I winced.

Apollo came on and said, "X-14-9-N-Q." Then there was static.

"Where the hell'd they go?" James asked.

Aaron kept listening for them, but there were just the miles of static. He started changing channels, looking for them.

All I could think to say was, "They're gone. Let's turn the thing off."

Aaron ignored me. He started flicking up and down the dial.

James said, "Christ, this is boring. We need girls or some weed. I'm gonna go take a leak." 
I said again for Aaron to give it up. I said it laughing, hoping to embarrass him, but I didn't have the ability to do that to him. He didn't even look up at me or change the rhythm of his twisting of the dial. I could hear the splash of James pissing against a stone.

Finally, like I knew he would from their code which wasn't hard to figure out, Aaron came across Apollo and Soyuz on Channel 19, three minutes later.

“. . no way that was Komarov," Soyuz said.

Apollo came on and said, "Let's go triple B to bridge to dam."

"Copy," Soyuz said.

"What the fuck was that?" Aaron asked. "What the fuck are they talking about?"

I didn't know why I said it, but from looking out over the rows of gravestones that sloped down the hill and then disappeared over the next hill, I turned and said, "They're talking about the Susquehanna River. They're taking Route 222 to the Columbia Bridge to the Harrinton Dam."

"Oh shit, we gotta go," he said.

James had just come back and sat down. He said he'd rather sit around and drink more. He then took a big sip, although it looked like there was the same amount inside as there'd been when we got here. Aaron was bored and that was when he was meanest, so he got up and started walking to the car without us. He turned back to face us.

"Let's go," he said.

Grandma used to say about me that I was in between worlds and didn't know which one I wanted to join for good. As we pulled onto the winding, narrow road after the bridge I figured she was probably right. I didn't know why I was going along with this, but there was a part of me that wanted to find them as much as Aaron did. I didn't know what we were doing, or why, but something about it seemed like I couldn't avoid it.

We got to the gravel parking lot above the dam. There were only four cars here and when I saw the two in the far corner, I knew they were theirs. We parked near the entrance under a street lamp, far away from them, and we got out. We started walking down to the overlook, Aaron still carrying the CB. 
I thought I recognized the shorter of the two from the maze of hallways at McArdle, but I didn't remember the taller one. I didn't know which one was Apollo and which one was Soyuz. They were standing at the railing, both of them leaning on it, looking down at the dam. I was breathing hard and started hoping Aaron would forget whatever he was thinking, but he had this look on his face that I'd seen before-full of hatred, or something more vague but just as scary.

Aaron stopped at the walkway leading out to the overlook and turned to me and James and said, "You know, you two are my very good buddies. I don't know what I'd do without such darn good buddies."

I shot a glance at Apollo and Soyuz in the dim light. They'd stopped talking and turned around. They looked at each other. All of us were quiet for a second, and then they started walking slowly with their heads down, towards us, trying to get off the overlook and back to their cars. I stepped back to give them room and pulled at Aaron's arm. James sort of stepped back, too. Aaron resisted me and stood right in the middle of the walkway so they couldn't pass. I could hear water rushing down the chute alongside the dam below us. I didn't see anyone else around even though there were the two other cars in the lot. I looked around hoping to see someone, to discourage Aaron from whatever he was about to do.

"C'mon," I said. "C'mon, Aaron, let's get going."

He just stood there and stared at Apollo and Soyuz. He turned on the $\mathrm{CB}$ and held it up to his mouth, even though they didn't have theirs. "Breaker breaker. I'm calling a couple of queer boys. Come back."

They stood in front of him with their heads down and he just stared at them. They looked really scared.

"Aaron, I gotta go." I turned and said to James, "C'mon, man." James wavered for a second, but I could tell he wanted to see how this was going to turn out. I took a few steps to leave. "I gotta get the car back. You guys better come if you want a ride."

Into the CB Aaron said, "Maybe the pussy boys'll give us a ride home. Whaddaya say, boys? Will you drive us home?"

"Don't be a dick, Aaron. Don't be a fucking dick." My voice was shaking. 
"Komarov?" the tall one asked. He was looking at me.

I completely froze. I wanted to cry like a little kid, like my mom does sometimes for no good reason when I'm just standing there trying to say something normal to her and have her say just one normal thing back for once. Aaron was standing right in the face of the tall one now.

"Who the fuck's Komarov?" Aaron asked. He turned and looked at me like I was some totally pathetic creature who'd just been beamed down in front of him.

I blinked and shrugged and shook my head no, I didn't know. I wanted to run away, but I was afraid to. Aaron reached out and grabbed the tall one and said, "Who the fuck is Komarov?"

Neither of them said anything.

James said then that he recognized both of them from school and he asked them their names. He was acting menacing, trying to be like Aaron just for fun.

The tall one looked right at me and he said slowly, like he hated everything about me, "My name is Soyuz."

"What?" Aaron asked. He looked back at me. "Do you know this guy, Zook?”

I didn't move.

He looked around like this whole situation had him completely confused and I could see he was getting really pissed. He looked at Apollo. "What's pee-wee's name here?" Aaron asked.

Apollo didn't say anything right away but then he stammered out, ". . . Hugh." He was barely able to speak he was so scared.

"His name's Apollo," said Soyuz, whose arm was getting squeezed hard by Aaron.

"Apollo, huh?" repeated James walking over to him. "Pee-wee Hugh Apollo."

Aaron then said to me, "And you're Komarov? Let me see if I got this . . Soyuz ..." he shook Soyuz's arm as he said it, then looked over at Apollo, “. .. Pee-wee Apollo. And Zookie here-you're Komarov, Zook. Right?” I was shit in his eyes, shit in everyone's eyes. "Tell me who this Komarov is, Zookie. I gotta know."

I don't think Aaron expected anyone to answer him, but Soyuz said, 
"He was a Russian cosmonaut."

"What?" Aaron said, shaking him by the arm.

Soyuz said it all looking right at me, his voice calm and so really frightening, his arm mercilessly squeezed by Aaron the whole time:

"He was a cosmonaut back in the sixties. He was the first person to orbit the moon. On the way back his entire navigation system went out on him and the ground crew figured he'd never make it."

I was doing everything I could not to cry.

"Tell us more," Aaron said sarcastically.

"The head of Russia got on the radio and promised him they'd give him a hero's burial and take care of his wife and kids. He was completely alone and his computer was out and they all knew he was dead. But he ended up using the stars to make it back to earth and then used the earth's horizon to line up the ship so it wouldn't burn during reentry. And he made it, no problem, which was like this impossible feat. ..."

Soyuz paused and shook his head in complete disgust at me.

"But then his chute didn't open," he continued. "The one thing he didn't have control over. And he plowed into the earth like a meteor and his ship completely disintegrated, with him in it."

We all just stood there. I couldn't even look at him and just stared at the ground in front of me.

Aaron said, after a pause, with just the water rushing below us, "James, will you do me a favor? Help me throw them over the railing."

James laughed the way he always did, and like Aaron's dog or something put Apol-Hugh into a full nelson and pretended like he was going to throw him over. Hugh barely resisted him. Soyuz never took his eyes off me.

Then Aaron turned and said, "Okay, Zook. One last chance. Punch him." He held Soyuz's arm behind his back like cops on TV do. I could see it hurt Soyuz. "Punch him in the fucking face. Hard." He stood him up straight so both their heads were right beside each otherSoyuz's acne-scarred and scared but daring me to do whatever I wanted to do, Aaron's smooth and awful and filled with something I didn't want to know. I could feel it all swelling up inside me. They were all looking at me, waiting for me to make some kind of move. 
The sound of water rushing at night makes a strange kind of sense to me. There's not much to say on that subject, except there's a lot that doesn't make sense to me. And this is all that was going through my head at the time: moving water sounds good, nice. Although even that little thing that made sense has since gotten muddied up like everything eventually does. When my grandmother died a couple years later, after I'd tried to give it a shot at the local college and all my mom had left was me, things got as muddy as they could get, and I can't see when that's going to change. But for just that moment I did understand something. Standing there on that overlook I knew that the water flying past the dam down below was a good thing, and that's something.

I just wish it had been enough, as I felt the pain shoot up my arm as my tight fist connected with something soft and then the hard, hard bone just underneath. Then the sound of static as a smiling Aaron dropped the CB and it landed right beside Soyuz, my friend, who I'd knocked to the ground. 